\title{
The Influence of Experience and Owner-Managers Education on SME Performance: Case of Motor Spares Enterprises at Kelvin Light Industries in Bulawayo
}

\author{
Ndlovu, N., Shumba, V., Vakira, E \\ Department of Business Management (Faculty of Commerce), \\ Lupane State University (LSU) Bulawayo, Zimbabwe \\ ndlovunj4@gmail.com
}

\begin{abstract}
The continued failure of small to medium enterprises and lack of growth of those that survive, continue to pose some challenges to the Zimbabwean economy. Lack of experience and education by ownermanagers of SMEs, is one of the major challenges impeding their survival and growth. The study sought to establish the influence of experience and owner-managers education on SME performance specifically focusing on motor spares SMEs at Kelvin Light Industries in Bulawayo. The objective of this study, therefore, was to analyse the relationship between experience and owner-managers education and the performance of SMEs. The descriptive research design was employed in this study. The researcher adopted stratified sampling technique supported by simple random technique to select participants from the population. Closed-ended questionnaires were used to collect data from owner-managers operating at Kelvin Light Industries. SPSS version 20 was used to analyse and present the data. The results of the study showed that there was a strong relationship between both education and experience of owner-managers on SME performance. The researcher recommends that owner-managers should continuously receive training on how to run and manage their SMEs. Owner-managers should employ human capital on merit which would give them a competitive advantage in business.
\end{abstract}

Keywords: SME performance, experience, education, owner-managers

\section{Introduction}

Small to Medium Enterprises (SMEs) are regarded as a veritable instrument of economic growth and poverty alleviation (Dumbu, 2014). They are being hailed as the seed-bed for the development of big entities and are the lifeblood of economic sustainability especially in this turbulent environment (Chivasa, 2014). SMEs have been expressed differently across the globe (Robu, 2013). Generally, SMEs are defined according to the number of employees, annual turnover and sales (Mudavanhu, Bindu, Chiguuswa and Muchabaiwa, 2011). However, in Zimbabwe, Small Enterprise Development Cooperation (SEDCO) refers to an SME as a firm that has the capacity to accommodate not more than 100 employees, with maximum annual sales of up to $\$ 830$ 000 (Majoni, Matunhu and Chaderopa, 2016). SMEs are playing a significant role in economic development in both developed and developing countries in the world (Sarpong, 2012). The extant literature has touted SMEs as the engine to economic recovery, contributing extremely in reducing poverty and playing a pivotal role in creating employment if well nurtured and supported (Hamad and Karoui, 2011; Sarpong, 2012). They cover $99 \%$ of European organisations; moreover, they provide $67 \%$ of the private sector jobs (Nguyen, Beeton and Halog, 2014). SMEs also contribute more than $50 \%$ of the total value-added created by entities in the European Union (Nguyen et al, 2014). In Zimbabwe's business circles, SMEs are appreciated remarkably as contributing more than $60 \%$ on employment (Majoni et al., 2016).

Ndlovu, (2015) a reporter of Chronicle noted that SMEs are contributing 50\% on Gross Domestic Product (GDP) and he also reported that Minister of Finance, Mr Chinamasa acknowledged the fact that SMEs are increasingly playing a key role in the economy thereby making a notable contribution to the Zimbabwean economy. However, despite their positive contribution to the economy, these emerging entities are failing to survive and those who survive are lagging behind in terms of growth and this has posed some challenges to the Zimbabwean economy (Dumbu, 2014). The situation is still prevailing as Motor Spares entities at Kelvin light industries in Bulawayo are finding it difficult to grow and survive. Furthermore, the dynamic and capricious changes in the economy have also affected the operations of SME's, compelling some to close shops and downsize (Chivasa, 2014). The failure of this sector has been exacerbated by a myriad of challenges such as owner-manager experience and level of education (Isaga, 2015). In the extant literature, it has been vindicated that human capital is the most influential factor that necessitates the prosperity of entrepreneurs (Mmari, 2014). Education and experience are major components of human capital which are critical to the 
owner-managers for their SME's to survive, especially in Zimbabwe were the business environment is turbulent.

Statement of the Problem: SMEs play an important role in ensuring economic growth, employment creation, income stability and poverty reduction in the whole world. However, despite the above importance, the continued failure of small to medium enterprises and lack of growth of those that survive continue to pose some challenges to the Zimbabwean economy. Performance of SMEs is deteriorating due to lack of various factors. The failure of these emerging enterprises subsequently results in employees being laid off contrary to the government's main objective of poverty reduction. However, despite the fact that the contribution of human capital is not new in business but in the Zimbabwean context it is yet to be fully realised, and that has motivated the researchers to carry out a research on the influence of experience, owner-manager' education on SME performance. However, education and experience have been touted as the panacea and this has resulted in it becoming ubiquitous. Colleges, training institutions and workshops are run almost every day with their objective being to educate people to enhance their potential in running SMEs. The question that remains is whether experience and owner-managers' education has an influence on SME performance?

\section{Research Objectives:}

- To analyse the relationship between experience and owner-managers' education and the performance of SMEs

- To determine the value that SMEs stand to gain if their owner-managers' have both experience and education

- To examine challenges that impede SMEs with owner-managers' without experience and higher educational level

\section{Research Questions:}

- Is there any relationship between experience and owner-managers' education and performance of SMEs?

- What are the values that SMEs stand to gain if owner-managers' have both experience and education?

- What are the challenges that impede SMEs with owner-managers' without experience and education?

\section{Statement of hypothesis:}

Hypothesis 1;

$\mathrm{H}_{0}$ : There is no relationship between experience and owner-managers' education on SMEs performance.

$\mathrm{H}_{1}$ : There is a relationship between experience and owner-managers' education on SMEs performance.

Hypothesis 2

$\mathrm{H}_{0}$ : Registration of SMEs is not influenced by experience and education of owner-managers

$\mathrm{H}_{1}$ : Registration of SMEs is influenced by experience and education of owner-managers

\section{Literature Review}

SMEs envelop a wide range of definitions and measures varying from country to country and between the sources reporting SME statistics (Amwele, 2013). Some of the commonly used criteria are the number of employees, total net assets, sales, and skill of labour and investment level (Abor and Adjasi, 2016). In nations like the USA, Britain and Canada, SMEs are viewed in terms of annual turnover and number of employees the organisation is able to employ formally. Britain defines small-scale entities with an annual turnover of 2 million pounds or less, with not more than 200 employees who are on a pay role (Afande, 2013). In Egypt, SMEs are viewed as organisations which employ more than 5 employees and fewer than 50 employees (Bouri, Breij, Diop, Kempner, Klinger and Stevenson, 2011).

In Zimbabwe, Ministry of SMEs separated small and medium enterprises, small entities are those who are not able to hire more than 50 employees while operating as a legally registered firm and medium entities are those who employ 75 to 100 human capitals (Majoni, et al, 2016). Zimbabwe Association of SMEs described an SME as a small entity which has a turnover of less than $\$ 240000$ and the asset value of less than $\$ 100000$. 
Medium enterprise has a turnover of more than $\$ 240000$ but less than $\$ 1000000$ in asset base (Chivasa, 2014). The above figures are presented in table 2.1 below.

Table 1: Synopsis of SME Definitions in Zimbabwe

\begin{tabular}{llll}
\hline Enterprise & Employees & Annual Turnover & Asset Base \\
\hline Small & 5 to 50 & $<\$ 240000$ & $<\$ 100000$ \\
Medium & 75 to 100 & $>\$ 240000$ & $<\$ 1000000$ \\
\hline
\end{tabular}

Importance of SMEs: SMEs are the backbone of many countries and the engine of economic growth in both developed and developing nations. They are being echoed worldwide as the real drive force which alleviates poverty because of their capabilities of employing a number of intellectual assets. They also contribute effectively to the GDP in different nations on the globe (Afande, 2013). The Organisation for Economic Cooperation and Development (OECD) states that more than 95\% SMEs employ more than $60 \%$ (Bouri et al, 2011). The Global Entrepreneurship Monitor (GEM) in 2010 articulated that countries like Angola, Ghana, South Africa Uganda and Zambia, their SMEs are improving (Yeboah, 2015). Maranga, (2014) expressed that, SMEs in Kenya are playing a prolific role in alleviating poverty, they created about 89, 9\% of employment and they contribute about 59\% to the GDP. In South Africa, SMEs are also instrumental because they are said to contribute 50 to $57 \%$ to the GDP and they also play a superb role in employment creation, it was estimated that they provide $61 \%$ of the labour force (Mahembe, 2011). In addition, the sector is also doing justice to the Zimbabwean milieu. Zimbabwe's Ministry of Finance propounded that, SME sector employs more than $60 \%$ of the country's labour force and contributes around 50\% of the country's GDP (Ruzivo Trust, 2013). The information above shows that SMEs play an important role in Zimbabwe's economy, with the ability to bring a fundamental solution in reducing the number of unemployed citizens. However, SMEs are failing because some of the owner-managers lack experience and education to run and manage these entities.

\section{Theoretical Framework}

Human Capital Theory: Human capital theory suggests that education and training is the best ingredient that makes organisations unique and different (Mmari, 2014). Ogubazghi and Muturi (2014) posit that human capital theory can be articulated as the resource that envelops experience, skills and knowledge which influence the success of an entity. There are several studies which postulate that the quality of human capital increase due to the time spent by owner-managers in training (Ogubazghi and Muturi, 2014). Sarwoko and Frisdiantara (2016) propounded that experience is the key factor that is used by owner-managers to outcompete their rivals. In business, there is bound to be competition, therefore owner-managers should be well equipped intellectually so that they can stand competition. Furthermore, Ng'ang'a, Ngugi, and Odhiambo (2014) concurred that education of owner-manager has a positive influence on the decision process of an entity. They also agree that the level of education of owner-manager influence organisational performance. The tacit knowledge of owner-manager is essential in both decision making and quality of products the organisation will produce at the end of the process (Ng'ang'a et al., 2014). The human capital theory emphasizes the importance of education to employees of any organisation. It conceptualises workers as embodying a set of skills which can be hired by owners of production to enhance performance. In addition, an organisation needs skills which cannot be imitated by competitors, hence these unique skills can act as the sustainable competitive advantage.

Empirical literature Review on experience and owner-manager education: There is a plethora of research conducted by different scholars in different continents throughout the world; their main objective was to establish the effects of experience and owner-manager education on SME performance. The following discussion will include some of the findings realised by other researchers.

Relationship between experience and owner-manager education on SME performance: Education has been always perceived as the important factor that influences the performance of any organisation (Mmari, 2014). Blackburn, Hart and WainWright (2013) carried out research in the United Kingdom about Small business performance: business strategy and owner-manager characteristics and it was concluded that high level of education by owner-manager increases their capabilities and survival chances of an enterprise. On 
the same vein, Brijlal, Naicker and Peters, (2013) carried out their research in South Africa about education and SMME business growth, and it was discovered that $73 \%$ of respondents acknowledged the fact that expansion of most businesses was influenced by the high level of education. Furthermore, Mmari, (2014) carried out research in Tanzania about the relationship between experience and owner-manager education on the performance of SMEs, a case study of garages in Arusha City and Moshi Municipality, and it was found that education of owner-manager influences the performance of an enterprise. To support the aforementioned statement, Isaga, (2015) also carried out research in Tanzania about owner-managers demographic characteristics and the growth of SMEs and it was disclosed that workshops attended by the owner-managers have a significant influence on the growth and sustainability of SMEs. It was also revealed that, for the business to be successful, owner-managers should improve their level of education (Mmari, 2014).

Woldie, Leighton and Adesua (2008) carried a study in Nigeria about the factors that influence the performance of SMEs and reported that performance differs with the level of education. An owner-manager who holds a degree performs better than owner-manager with a low level of education (Mmari, 2014; Yeboah, 2015). However, training is a continuous process; and it is necessary for owner-managers to upsurge their knowledge by attending different workshops and enrolling with different educational institutions to further their educational levels. Level of education plays a prolific part in the performance of different entities. However, some researchers have argued that education is insignificant on the performance of SMEs.

Amarteifio and Mensah, (2013) carried out research in Accra, Ghana about the level of education, experience and performance of SMEs and it was concluded that education is not that important on the performance of SMEs. They noted that, an entrepreneur only needs basic education for his or her entity to positively perform. Kamunge, Njeri and Tirimba (2014) also argued that the lack of managerial skills affect the performance of an entity but on a moderate scale. Experience is defined as knowledge and skills attained by observing and physically dealing with a number of tasks encountered during the organisation's work processes (Soriano and Castrogiovanni, 2012). Some researchers have reported different perceptions about the relationship between experience and performance of enterprises. Some academies have revealed that experience enhances the positive performance of an entity, while others argued that experience is ineffective when it comes to a company's performance (Woldie et al., 2008).

Soriano and Castrogiovanni, (2012) carried out a research on the impact of education, experience and inner circle advisors on SME performance, and it was discovered that experience gained from previous work which is different from your own business has a negative bearing on profitability, however, it was further revealed that experience from previous work on the same industry correlate to productivity (Soriano and Castrogiovanni, 2012). The notion above was also supported by Chachar, (2013) who carried out research in Pakistan about the impact of owner-managers education and work experience on the growth of handicraft SMEs. He established that the higher the number of years of work experience the higher the growth of enterprises with respect to profits, sales, number of employees and customer base. Amarteifio and Mensah (2013) also established that work experience is not the only important instrument which enables improvement of SME performance. They articulated that age can also play an important role in SME performance.

Value that SMEs stand to gain if their owner-manager has both experience and education: Brijlal et al. (2013) in their research revealed that, there is a higher chance of increasing labour force if the ownermanager is highly educated. Soriano and Castrogiovanni, (2012) reported that owner-managers experience is critical because the organisation will be able to attract more customers and suppliers; thereby increasing their market share. In addition, experience helps the owner-manager to exploit relevant material which is valued by the customers (Soriano and Castrogiovanni, 2012). Smit and Watkins, (2012) posit that education and experience of entrepreneurs assist them to apply relevant strategies especially in the turbulent business environment. Some empirical studies have also suggested that managerial experience in emerging economies pave a way on how to embrace relevant policies which can glue in positive results for an entity (Shava and Rungani, 2016). However, the value that can be gained by enterprises with owner-manager holding high educational qualifications is that, the risk is managed amicably, therefore this enforce the growth of an organisation. Sarwoko et al. (2013) cement that, education and experience are critical to the survival and 
growth of an enterprise. They further relay that experience and education enhance owner-manager to recognise the opportunity and utilise it.

Challenges that impede SMEs with owner-managers without experience and high level of education: It has been established by previous literature that experienced and highly educated owner-managers are influential on the performance of any organisation. However, some previous studies have also highlighted that, there are several challenges that are faced by inexperienced owner-managers. Chachar, (2013) opine that education and experience have positively influenced the growth of any organisation. Education is influential on the sales, profit and number of human capital employed by the enterprise (Chachar, 2013). If the owner-manager is lagging behind in terms of education and experience, the organisation will employ a limited number of employees and furthermore, their sales and profits would be very low. If the ownermanager is inexperienced and uneducated, the organisation will not survive, hence, it will close shop within a short period of time in business (Hove and Chikungwa, 2012). It is essential for the researchers to test if registration of entities is influenced by owner-managers education and experience.

Registered SME's are owned by educated and experienced owner-managers: There are a number of SMEs which are mushrooming in the business circles. However, a number of these SMEs are not being registered. It was noted that informal entities do not register because regulations of different nations are too complex (Bruhn and Loeprick, 2016). However, some of the reasons which necessitate failure of registration of SMEs by owner-managers are that, they lack the knowledge and experience on how to go about it. It is also important to note that; some of the requirements which are required by policymakers are too many and sometimes complex, thereby making it difficult for owner-managers to register their enterprises.

\section{Research Methodology}

The descriptive research design was employed by the researchers to describe characteristics of a population being studied. It is a research method that uses various forms of data as well as incorporating human experience. Descriptive research provides answers as to who, what, where and how questions on the influence of experience and owner-manager education on SME performance (Creswell, 2011). However, the researchers applied this research design to get an insight of the impact of experience and education of ownermanager on SMEs. Philosophical approach of interpretivism was employed moving towards positivism to guide the whole research. Furthermore, this study adopted a mixed method approach, which represents the collection, analysis and interpretation of quantitative and qualitative data in a single study (Creswell and Plano, 2011). Mixed method approach is aimed at increasing the validity of evaluation and the research findings, which essentially combines both the qualitative and quantitative approaches (Mertens, 2009).

A deductive research approach was used to get answers in response to research questions which were crafted in chapter one of the study. Deductive research approach involves testing of the theory which underpins the study, for example in this research, the human capital theory was applied in literature review which was discussed in chapter two (Mmari, 2014). The data was quantified and examined to provide insights which were used to form the conclusion. Kelvin Light industry was randomly used in this study. The information obtained from Bulawayo City Council, unfolded that there are 53 motor spares which are registered and 56 were operating while they were not registered, therefore total population was 109 . Researchers calculated one-third of the total population and the targeted population was 16 participants from registered entities and 17 participants from unregistered SMEs. The table below present the total and targeted population of the sample.

Table 2: Total and targeted population of sample

\begin{tabular}{lll}
\hline Respondents & Total population & Target population \\
\hline Owner-Managers (Registered) & 53 & 16 \\
Owner-Manager (Not Registered) & 56 & 17 \\
Total & 109 & 33 \\
\hline
\end{tabular}


However, for the purpose of yielding valid results, the researchers increased the number of targeted population from 33 to 40 owner-managers' participants. The targeted population was so because the researchers saw it worthy to deal with only owners of SMEs. On that same vein, Roscoe (1975) alluded that the sampling size should be more than 30 , but less than 530 . The proposed sampling size is regarded as enough to produce effective results. Due to the above two distinct subpopulations, stratification sampling technique was employed. Stratification sampling technique is the process of dividing members of the population into homogeneous subgroups before sampling (Frerichs, 2008). For instance, this research includes two subpopulations which are registered and unregistered motor spares shops, therefore stratification sampling technique was the best technique to employ because it is less prone to bias. Random sampling was employed to randomly select representatives from both registered and unregistered SMEs (Cooper and Schindler, 2011). The researcher employed closed-ended questions because of its inclusiveness in nature since they were premeditated to produce easily quantifiable data.

Reliability of the Study: The researchers formulated 28 questionnaires to assess the influence of experience and owner-managers' education on SME performance. 22 of the questions were in a five point Likert scale ranging from "strongly disagree" to "strongly agree". Before the questionnaire was finally adopted the validity of the instrument were measured with the aid of the Statistical Package for Social Sciences (SPSS) software package version 20. Cronbach's alpha was run on all of the questions in order to ascertain the reliability of the questionnaire.

Data Analysis and Presentation: To conduct quantitative research it is necessary to code the data from the questionnaire. This process was done to refine data into simple analysable components. Coded data from questionnaires were loaded into the SPSS an electronic tool used for data analysis, descriptive statistics, graphical presentations as well as data documentation (Cooper and Schindler, 2011). Data were analysed and presented in a clear, readable manner allowing the construction of clear relationships in the data.

\section{Findings}

Relationship between experience and owner-manager education on SME performance

Table 3: Regression Analysis results on sales

\begin{tabular}{|c|c|c|c|c|}
\hline \multicolumn{5}{|c|}{ Model Summary } \\
\hline Model & $\mathrm{R}$ & R Square & Adjusted R Square & Std. Error of the Estimate \\
\hline 1 & $.887^{a}$ & .786 & .769 & .613 \\
\hline
\end{tabular}

Predictors: (Constant), Years of work experience, Professional Qualification: The research showed that there is a positive relationship between experience and owner-manager education on SME performance. The results which were obtained from regression analysis between work experience and professional qualification on sales of SMEs operating at Kelvin Motor Spares Light Industry revealed that $\mathrm{R}^{2}$ is at $78.6 \%$ which show that both experience and education has a positive impact on the performance of SMEs. The results are consistent with results of Blackburn, et al. (2013) and Mmari, (2014) who were discussed in chapter two of the research who concluded that both education and experience of owner-managers' have significant effects on SME performance. Therefore, hypothesis number $1 \mathrm{H}_{1}$ which states that, there is a relationship between experience and owner-managers' education on SMEs performance is accepted.

Value that SMEs stand to gain if their owner-manager have both experience and education

Table 4: Regression Analysis of customer base

\begin{tabular}{lllll}
\hline Model Summary & & & & \\
\hline Model & $\mathrm{R}$ & R Square & Adjusted R Square & Std Error of the Estimate \\
1 & $.855^{\mathrm{a}}$ & .731 & .714 & .613 \\
\hline
\end{tabular}


Predictor: (Constant), Years of work experience, Professional Qualification: It was established that, owner-managers with both experience and better level of education enhances the enterprise to increase their customer base, increased number of intellectual assets and growth. The regression analysis was employed to test if experience and education significantly impact customer base of SMEs. The results indicated that $\mathrm{R}^{2}$ is $73.1 \%$ which implies that education and experience are critical in up surging number of customers. To support the above results, the chi-square test was also engaged.

Table 5: Chi-Square Tests between headcount and professional qualification

\begin{tabular}{llll}
\hline Chi-Square Tests & & & \\
\hline & Value & Df & Asymp. Sig (2-sided) \\
Pearson Chi-Square & $33.955^{\mathrm{a}}$ & 12 & .001 \\
Likelihood Ratio & 30.970 & 12 & .002 \\
Linear-by-Linear Association & 19.740 & 1 & .000 \\
N of Valid Cases & 35 & & \\
\hline
\end{tabular}

19 cells (95.0\%) have expected count less than 5. The minimum expected count is .23

Chi-square was employed to assess the relationship between both experience and education of ownermanagers on headcount and it was indicated that p-value was less than our chosen significant level of 0.05 and therefore, it was concluded that both independent variables and headcount are related. Hence, there was a significant association between the independent variables and headcount. The results were constant with the results of Brijlal et al. (2013) which were discussed in chapter two, who concluded that business expansion was being influenced by the high level of education.

\section{Challenges that impede SMEs with owner-managers without experience and high level of education}

Table 6: Cross tabulation between professional qualification and owner-managers' ability to apply for a loan

The owner-manager is able to apply for a loan to any financial institution

*Professional Qualification: Crosstabulation

\begin{tabular}{|c|c|c|c|c|c|c|c|}
\hline & & & Profes & nal Qualific & & & Total \\
\hline & & & None & Certificate & Diploma & Degree & \\
\hline The owner- & Strongly & Count & 2 & 0 & 0 & 0 & 2 \\
\hline manager is & Disagree & \%within the owner- & $100 \%$ & $0.0 \%$ & $0.0 \%$ & $0.0 \%$ & $100 \%$ \\
\hline & & manager is able to & & & & & \\
\hline apply to & & apply for a loan to any & & & & & \\
\hline financial & Disagree & Count & 0 & 3 & 0 & 0 & 3 \\
\hline institution & & $\%$ within the owner- & $0.0 \%$ & $100 \%$ & $0.0 \%$ & $0.0 \%$ & $100 \%$ \\
\hline & & $\begin{array}{l}\text { manager is able to } \\
\text { apply for a loan to any } \\
\text { financial institution }\end{array}$ & & & & & \\
\hline & Neither & Count & 2 & 2 & 1 & 0 & 5 \\
\hline & $\begin{array}{l}\text { disagree } \\
\text { nor agree }\end{array}$ & $\begin{array}{l}\text { \%within the owner- } \\
\text { manager is able to } \\
\text { apply for a loan to any } \\
\text { financial institution }\end{array}$ & $40 \%$ & $40 \%$ & $20 \%$ & 0 & $100 \%$ \\
\hline & Agree & Count & 0 & 3 & 10 & & 14 \\
\hline & & $\begin{array}{l}\text { \%within the owner- } \\
\text { manager is able to } \\
\text { apply for a loan to any } \\
\text { financial institution }\end{array}$ & $0.0 \%$ & $21.4 \%$ & $71.4 \%$ & $7.1 \%$ & $100 \%$ \\
\hline & Strongly & Count & 0 & 0 & 6 & 5 & 11 \\
\hline & Agree & \%within the owner- & $0.0 \%$ & $0.0 \%$ & $54.5 \%$ & $45.5 \%$ & $100 \%$ \\
\hline
\end{tabular}


manager is able to

apply for a loan to any

Total financial institution

Count
\%within the owner-
manager is able to
apply for a loan to any
financial institution

4

$11.4 \%$
8

$22.9 \%$
17

$48.6 \%$
6

$17.1 \%$
35

$100 \%$

The results obtained from the cross tabulation above indicated that those owner-managers without any professional qualification, $100 \%$ strongly disagreed that they are able to apply for a loan, $100 \%$ of holders of certificates disagreed that they are able to apply for a loan. On the other hand, $71.4 \%$ of diploma holders agreed that they are able to apply for a loan, $54.5 \%$ of them strongly agreed that they are capable. Furthermore, from the degree holders, $45.5 \%$ strongly agreed and $7.1 \%$ also agreed that they are able to apply for a loan to any financial institution. Therefore, the results show that education plays a big role in accessing financial help. It can be concluded that failure to apply for a loan is another bottleneck which holds back SME owner-managers to perform as expected. These results are also consistent with findings of who carried out their research in the United Kingdom about barriers faced by SMEs in raising bank finance and they concluded that graduates had the least difficulties raising finance. The regression analysis below also revealed the same results. Therefore, hypothesis number $2 \mathrm{H}_{1}$ which states that, registration of SMEs is influenced by experience and education of owner-managers is accepted.

\section{Registered SME's are owned by educated and experienced owner-managers}

Table 7: Regression analyses between professional qualification and tax returns

\begin{tabular}{lllll}
\hline Model Summary & & & & \\
\hline Model & $\mathrm{R}$ & R Square & Adjusted R Square & Std Error of the Estimate \\
1 & $.831^{\mathrm{a}}$ & .691 & .682 & .734 \\
\hline
\end{tabular}

Predictors: (Constant, Professional Qualification

The frequency analysis results had indicated that 13(37.1\%) of respondents agreed that their tax returns are in place, $10(28.6 \%)$ strongly agreed that they have tax returns in place. On the other hand, 10(28.6) of participants disagreed that their tax returns are in place and 2(5.7\%) strongly disagreed. However, this shows that there are some owner-managers who are operating whilst they are not legally registered by authorities. The researcher seeks to explore if professional qualification influences SMEs to have tax returns in place. Regression analysis was also employed. From the results obtained on the regression analysis table above, $\mathrm{R}^{2}$ is $69.1 \%$ which demonstrate that professional qualification influences SMEs to have tax returns in place. However, researchers have concluded that level of education positively influences registration of SMEs.

\section{Conclusion}

The results show that experience and owner-managers' education is significant on SME performance. It was revealed that owner-managers with a high level of education and relevant experience are able to increase the number of their intellectual assets, customers and their sales. Furthermore, the research demonstrated that owner-managers without education and experience are facing some challenges in accessing financial support from financial institutions as compared to owner-managers with experience and better level of education. It was also unfolded that education and experience of owner-managers' influences registration of SMEs.

Recommendations: Recommendations to follow were gathered after a thorough understanding of the problem and assessing the data obtained from the owner-managers' of SMEs operating at Kelvin Light Industry. The recommendations proposed are critical and of versatile to all SMEs in Zimbabwe and abroad. On the same vein, recommendations cannot be fruitful on their own but they need a commitment from both the owner-managers and the government. 


\section{Policy Implications}

Government Should Provide Training Programmes Specifically for SME Owner-Managers: Education and experience of owner-managers was found to be influential on the performance of Motor Spares SMEs. Owner-managers should continuously further their studies to remain relevant and competitive. The government should support SME owners by increasing the number of workshops which offer training on how to effectively manage emerging entities. It is also recommended that the training they receive should help them to run their businesses ethically and professionally. There is also a need for SMEs to embrace corporate governance principles in their operations. Furthermore, the government should support SMEs financially so that they may augment their capital base.

Areas for further research: The research has given an insight into the area of education and experience of owner-managers and how these two variables impact performance of SMEs who are into buying and selling vehicle spare parts at Kelvin Light Industries in Bulawayo. The following aspects should be considered for future research: Research related to SMEs covering the whole of Zimbabwe. If possible the research should cover SMEs who are into manufacturing and service delivery to make an informed judgment with a larger sample. There is need also to do a similar study on different economic conditions. Future studies might consider using different research paradigm. Triangulation on the basis of more qualitative data and other different variables in addition to education and experience, for example age and gender. In addition, an extension of this work can be comparisons between Zimbabwe and other countries like South Africa, Botswana and Zambia because entrepreneurs who are buying and selling vehicle spare parts are mushrooming even across borders.

\section{References}

Abor, J. \& Adjasi, C. K. D. (2016). Corporate Governance and the Small and Medium Enterprise Sector: Theory and Implications, Corporate Governance Journal of Business Society, 7(2), 111-122.

Afande, F. O. (2013). Adoption of Corporate Governance Practices and FinancialPerformance of Small and Medium Enterprises in Kenya, Research Journal of Finance and Accounting, 6(5), 36-74.

Amarteifio, E. N. A. \& Mensah, J. V. (2013). Level of Education, Experience and Performance of Small and Medium Enterprise in the Accra Metropolis', Ghana, University of Cape Coast.

Amwele, H. N. (2013). An Empirical Investigation into the Factors Affecting the Performance of SMEs in the Retail Sector in Windhoek, Namibia, Polytechnic of Namibia.

Blackburn, R. A., Hart, M. \& Wainwright, T. (2013). Small Business Performance: Business Strategy and Owner-Manager Characteristics, Journal of Small Business and Enterprises Development, 20(1), 8-27.

Bouri, A., Breij, M., Diop, M., Kempener, R., Klinger, B. \& Stevenson, K. (2011). Report on Support to SMEs in Developing Countries Through Financial Intermediaries, Dalberg, Geneva.

Brijlal, P. \& Naicker, V. (2013). Education and SMME Business Growth: A. Gender Perspective from South Africa, International Business and Economics Research Journal, 12(8), 855-867.

Bruhn, M. \& Loeprick, J. (2016). Small business Tax Policy and Informality: Evidence from Georgia, International Tax and Public Finance, 23(5), 834-53.

Chachar, A. A. (2013). The Impact of Owners' Education and Work Experience on the Growth of Handicraft SMEs in Hyderabad Region Pakistan, University of Bedfordshire, Luton.

Chivasa, S. (2014). Entrepreneurship Culture Among SMEs in Zimbabwe. A Case of Bulawayo SME's, International Journal of Economics, Commerce and Management, 2(9), 1-13.

Cooper, D. R. \& Schindler, P. S. (2011). Business Research Methods, (11 th Ed), McGraw-Hill-Irwin, New York.

Creswell, J. W. \& Plano, C. V. L. (2011). Designing and Conducting Mixed Methods Research, (2nd Edition), CA: Sage, Thousand Oaks.

Dumbu, E. (2014). An Evaluation of the Management of Micro and Small Enterprises (Mses) In Zimbabwe: A Case Study of the Manufacturing Mses in Masvingo Urban', Zimbabwe, Zimbabwe Open University.

Frerichs, R. R. (2008). Simple Random Sampling, Accessed at www.randomsampling.com on 24/02/17 at 22:57 hours.

Hamad, S. B. \& Karoui, A. (2011). The SMEs Governance Mechanisms Practices and Financial Performance: Case of Tunisian Industrial SMEs, International Journal of Business and Management, 6(7), 216-226. 
Hove, P. \& Chikungwa, T. (2012). Internal Factors Affecting the Successful Growth and Survival of Small and Micro Agri-business Firms in Alice Communal Area', Journal of Economics, 4(1), 57-67.

Isaga, N. (2015). Owner-Managers Demographic Characteristics and the Growth of Tanzanian Small and Medium Enterprises, International Journal of Business and Management, 10(5), 1-14.

Kamunge, M. S., Njeru, A. \& Tirimba, O. I. (2014). Factors Affecting the Performance of Small and Micro Enterprises in Limuru Town Market of Kiambu County, Kenya, International Journal of Scientific and Research Publications, 4(1)2, 1-20.

Mahembe, E. (2011). Literature Review on Small and Medium Enterprises' Access to Credit and Support in South Africa National Credit Regulator (NCR)', Underhill Solutions (UCS) Publications, Pretoria.

Majoni, T. Matunhu, J. \& Chaderopa, B. (2016). SMEs Policies and Challenges: A Comparative Analysis of Zimbabwe and South Korea', International Journal of Science and Research Publications, 6(6), 377385.

Maranga, G. M. (2014). The Effects of Corporate Governance on Financial Performance of Small and Medium Enterprises in Nairobi County, Kenya, Business Administration School of Business, University of Nairobi.

Mertens D. M. (2009). Transformative Research and Evaluation, New York, Guilford.

Mmari, G. A. (2014). Influence of Education on Performance of SMEs: Experience from Vehicle Garages in Arusha City and Moshi Municipality, Tanzania, International Journal of Research Reports Series, 2(2), $1-28$.

Mudavanhu, V., Bindu, S., Chiguuswa, L. \& Muchabaiwa, L. (2011). Determinants of Small and Medium Enterprises Failure in Zimbabwe: A Case Study of Bindura, International Journal of Economics Research, 2(5), 82-89.

Ndlovu, P. (2015). 2016 Budget: Divergent Optimism for SMEs, the Chronicle, Bulawayo, 03 December, p. 05.

Nganga, P. K., Ngugi, P. K. \& Odhiambo, R. (2014). Influence of Owner/Manager Personal Characteristics on the Demand for Business Development Service by Micro and Small Enterprises from the Upper Echelons Theory, International Journal of Business and Social Science, 5(6), 1-7.

Ogubazghi, S. K. \& Muturi, W. (2014). The Effect of Age and Educational level of Owner/Managers on SMMEs' Access to Bank in Eritrea: Evidence from Asmara City, American Journal of Industrial and Business Management, 4, 632-643.

Robu, M. (2013). The Dynamic and Importance of SMEs in Economy, The USV ANNALS of Economics and Public Administration, 13(1), 84-89.

Ruzivo Trust. (2013). Micro, Small and Medium Enterprise (MSME) Sector, Available at www.ruzivo.co.zw accessed on 20/02/2017 at 13:04 hours.

Sarpong, D. (2012). Micro, Small and Medium Scale Enterprises in Ghana: Challenges and Prospects: A Case Study of Sekondi-Takoradi Metropolis, Accessed at www.ccsenet.org/journal/index on 27/02/2017 at 11:37 hours.

Sarwoko, E. \& Frisdiantara, C. (2016). Growth Determinants of Small Medium Enterprises (SMEs), Universal Journal of Management, 4(1), 36-41.

Shava, H. \& Rungani, E. C. (2016). Influence of Gender on SME Performance in Emerging Economies, Acta Commercii - Independent Research Journal in the Management Sciences, 1-9.

Shumba, V., Manzini, S. \& Ndlovu, N. (2015). The Effects of Separating Ownership and Control on The Performance of Retail Stores in Southern Zimbabwe, International Journal of Economics, Commerce and Management, 2 (6), 1-17.

Smit, Y. \& Watkinds, J. A. (2012). A Literature Review of Small and Medium Enterprises (SME) Risk Management Practices in South Africa, African Journal of Business Management: Victoria Island, 6(21), 324-330.

Soriano, D. R. \& Castrogiovanni, G. J. (2012). The Impact of Education, Experience and Inner Circle Advisors on SME Performance: Insights from a Study of Public Development Centers, Journal of Small Business Economics, 38, 333-349.

Yeboah, M. A. (2015). Determinants of SME Growth: An Empirical Perspective of SMEs in the Cape Coast Metropolis, Ghana, The Journal of Business in Developing Nations, 14, 1-31.

Woldie, A., Leighton, P. \& Adesua, A. (2008). Factors Influencing Small and Medium Enterprises (SMEs): An Exploratory Study of Owner/Manager and Firm Characteristics, Journal of Banks and Bank Systems, 3(3), 5-9. 